\title{
EKSISTENSI DAN KERAGAAN IKAN DI DAERAH ALIRAN SUNGAI CIBANTEN
}

\section{FISH EXISTENCE AND DIVERSITY IN CIBANTEN RIVER SYSTEM}

\author{
Ishaaq Saputra ${ }^{1 \#}$, Muklasin ${ }^{1}$, Forcep Rio Indaryanto ${ }^{2}$, dan Sinung Rahardjo ${ }^{3}$ \\ ${ }^{1}$ Stasiun Karantina Ikan Pengendalian Mutu dan Keamanan Hasil Perikanan Merak - Banten \\ Jl. Raya Tol Merak Km.01 No.01 Pelabuhan Penyeberangan Merak - Banten \\ ${ }^{2}$ Jurusan Perikanan, Fakultas Pertanian Universitas Sultan Ageng Tirtayasa \\ Jl. Raya Jakarta - Serang, Km.4, Serang - Banten \\ ${ }^{3}$ Sekolah Tinggi Perikanan Jakarta \\ Jl. AUP Pasar Minggu Jakarta Selatan 12520 \\ E-mail: isaputra.6m2@gmail.com
}

(Diterima: 29 Oktober 2019; Diterima setelah perbaikan: 20 November 2019; Disetujui: 21 November 2019)

\begin{abstract}
ABSTRAK
Sungai Cibanten merupakan salah satu sungai yang memiliki peranan penting di Provinsi Banten. Sungai ini memiliki hulu yang berlokasi di Situ Cibanten, Ciomas, Kabupaten Serang. Tujuan dari penelitian ini adalah untuk mengevaluasi keberadaan, komposisi, keanekaragaman dan keseragaman ikan di Sungai Cibanten. Pada penelitian ini, diperoleh ikan sebanyak 135 ekor ikan. Berdasarkan hasil identifikasi spesies yang dilakukan, ikan - ikan tersebut berasal dari lima family ikan yaitu Cyprinidae, Loricariidae, Palaemonidae, Zenarchopteridae dan Penaeidae. Selain itu, diperoleh sejumlah tujuh spesies ikan termasuk satu ikan asing yaitu ikan sapu-sapu (Pterygoplichthys pardalis). Hasil analisa menunjukkan bahwa indek keanekaragaman, keseragaman dan dominasi pada seluruh titik sampling masih dalam kondisi normal. Namun demikian, dengan ditemukannya ikan sapu-sapu ( $P$. pardalis) pada sistem Sungai Cibanten mungkin akan memiliki dampak negatif terhadap ekologi sungai. Penelitian lebih lanjut dibutuhkan untuk mengevaluasi lebih lanjut keberadaan ikan sapu-sapu dan ikan asing lainnya yang memiliki potensi bahaya terhadap ekologi Sungai Cibanten.
\end{abstract}

KATA KUNCI: Cibanten; keanekaragaman; keragaan; indeks

\section{ABSTRACT}

Cibanten river system is an important river system in Province of Banten. The upstream of this river system is located at Situ Cibanten, District Ciomas, Serang regency. Objectives of this study is to evaluate the fish existence, diversity, and uniformity in Cibanten river system. In this study 135 individual fish were collected. Research has shown that five family and seven fish species include one alien fish species (Pterygoplichthys pardalis) were collected from this location. Results indicated that the diversity, uniformity and domination index in all sampling station is under normal conditions. However, surprising finding of Amazonian mouth sucker catfish (Pterygoplichthys pardalis) in this river system may have signifincant ecological consequences in the river system. Further study is required to evaluate the availability of the other allien species which is posing to potential threats for the river system.

KEYWORDS: Cibanten; diversity; domination; index

\#Korespondensi: Stasiun Karantina Ikan Pengendalian Mutu dan

Keamanan Hasil Perikanan Merak

E-mail: isaputra.6m2@gmail.com 


\section{PENDAHULUAN}

Sungai Cibanten membentang dari bagian tengah hingga utara Provinsi Banten. Sumber mata air Sungai Cibanten berasal dari Gunung Karang di Kecamatan Ciomas, Kabupaten Serang. Sungai ini mengalir ke arah utara melalui beberapa kecamatan dan bermuara di Teluk Banten. Sungai Cibanten dimanfaatkan oleh masyarakat sekitar daerah aliran sungai untuk keperluan sehari-hari seperti mandi dan mencuci. Penelitian tentang kondisi perairan Situ Cibanten berdasarkan indek keragaman plankton yang ada di perairan tersebut menunjukkan bahwa Situ Cibanten sudah tercemar berat (Saifullah et al., 2015).

Keberadaannya yang begitu strategis bagi masyarakat, membuat sungai Cibanten merupakan salah satu sungai penting di Kabupaten Serang, Provinsi Banten. Ekspedisi telah dilakukan pada tahun 2015 oleh Balai Pelestarian Cagar Budaya Serang. Gumelar (2016) melaporkan bahwa di Situ Cibanten yang merupakan hulu aliran sungai Cibanten telah ditemukan beberapa organisme air antara lain keong, udang air tawar, ikan guppy, ikan seribu dan tumbuhan azzola. Namun demikian, sampai saat ini belum ada data mengenai jenis maupun keragaan ikan yang ada di aliran sungai Cibanten. Pendataan jenis-jenis ikan yang berada di suatu perairan sangatlah penting untuk mengetahui komposisi dan status keberadaan ikan baik ikan endemik maupun ikan introduksi. Sehingga, bahaya ekologis yang mungkin ditimbulkan oleh adanya ikan introduksi yang bersifat invasif mungkin dapat dicegah lebih awal (Eby et al., 2006). Selain pengaruh aktivitas manusia, populasi ikan asli juga dapat dipengaruhi oleh predasi dan kompetisi ikan jenis lain (Herder et al., 2012) dan dalam jangka panjang bisa merubah struktur habitat (Croocks, 2002).

Kementerian Kelautan dan Perikanan melalui Peraturan Menteri Kelautan Nomor 41 tahun 2014 telah menetapkan 152 jenis ikan yang bersifat invasif. Penerbitan peraturan tersebut bertujuan untuk melindungi keanekaragaman hayati perikanan Indonesia. Ikan-ikan tersebut merupakan jenis ikan yang sudah teridentifikasi maupun berpotensi sebagai ikan yang bersifat invasif yang berasal dari luar negeri. Meskipun demikian, di Indonesia juga terdapat ikan lokal yang bersifat invasif (Haryono et al., 2016). Introduksi ikan invasif berupa spesies asing telah merubah komunitas biologi secara dramatis dan berkontribusi terhadap penurunan dan musnahnya sejumlah spesies, termasuk beberapa ikan air tawar (Lever, 1996; Peh, 2010). Oleh karena itu identifikasi ikan invasif dan asing sangat diperlukan untuk mempertahankan keanekaragaman hayati ikan di suatu ekosistem.

Penelitian ini bertujuan untuk mengetahui keberadaan, komposisi, keanekaragaman dan keseragaman ikan yang berada di aliran Sungai Cibanten, Kabupaten Serang. Penelitian memiliki manfaat antara lain: 1) sebagai bahan informasi keberadaan jenis-jenis ikan di aliran Sungai Cibanten termasuk ikan asing maupun ikan invasif, 2) Sebagai data awal dalam penetapan kebijakan terkait pemanfaatan Sungai Cibanten.

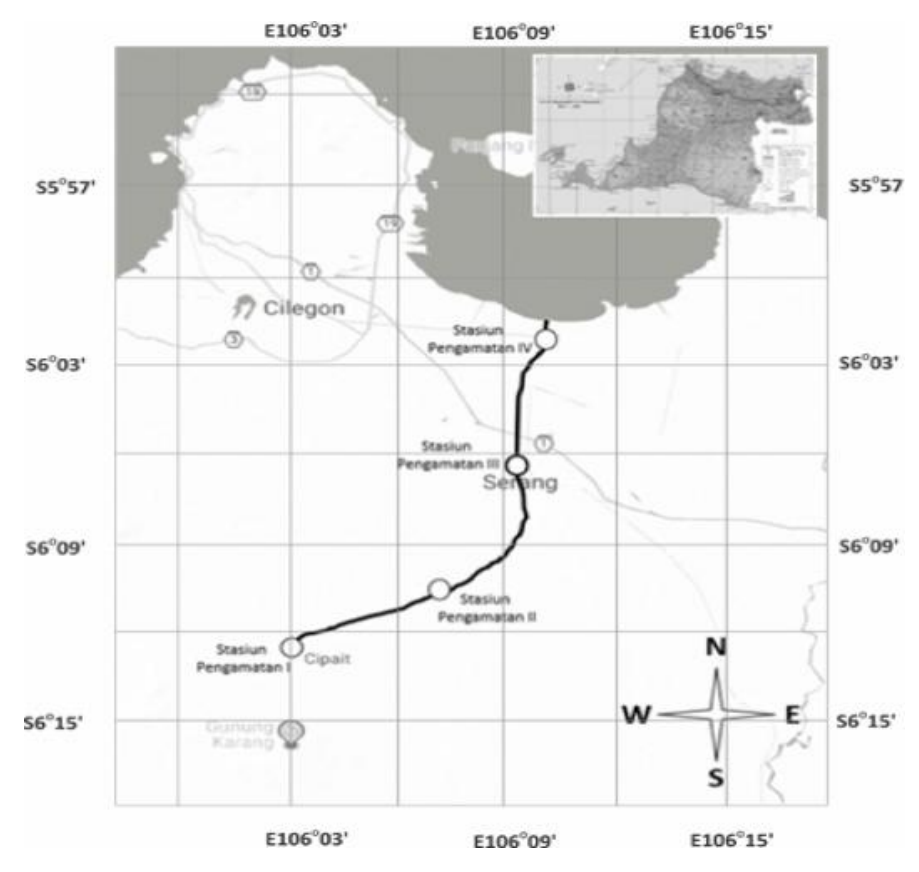

Gambar 1 Lokasi Pengamatan dan Pengambilan Sampel.

Figure 1 Observation and Sampling Location. 


\section{BAHAN DAN METODE}

\section{Waktu, titik sampling dan alat sampling}

Kegiatan pengambilan sample ikan dilakukan Bulan Maret 2017 di daerah aliran sungai Cibanten dengan titik sampling meliputi Hulu Sungai Cibanten, Kaujon dan Bendungan Karet (Keraton Kaibon). Alat yang digunakan menyesuaian dengan kondisi alam titik sampel dan alat yang digunakan adalah jaring insang berbahan nylon dengan ukuran mata jaring 1 cm dan jala lempar ukuran 0.5 inchi. Waktu pengambilan sampel yaitu pada pagi hari pada pukul 09.00 WIB sampai sore pukul 16.00 WIB.

Berdasarkan data Global Positioning System, lokasi pengambilan sample di DAS Cibanten terletak pada empat titik masing-masing pada koordinat $106^{\circ} 02^{\prime} 48.2^{\prime \prime} 6^{\circ} 13^{\prime} 07.0^{\prime \prime} \mathrm{S}$. Hulu sungai Cibanten dan Kaujon terletak pada koordinat $106^{\circ} 02^{\prime} 44.2^{\prime \prime} \mathrm{E}$ $6^{\circ} 13^{\prime} 05.6^{\prime \prime} \mathrm{S}$ dan $106^{\circ} 09^{\prime} 02.9^{\prime \prime} \mathrm{E} 6^{\circ} 07^{\prime} 21.4^{\prime \prime}$ S. Sedangkan untuk Bendungan Karet terletak pada koordinat $106^{\circ} 09^{\prime} 43.0^{\prime \prime} \mathrm{E} 6^{\circ} 02^{\prime} 31.6^{\prime \prime} \mathrm{S}$. Pengambilan sampel dilakukan dengan metode purposive sampling, dimana lokasi ditentukan secara sengaja.

\section{Identifikasi Ikan}

Seluruh ikan yang diperoleh diidentifikasi hingga tingkat spesies berdasarkan studi literatur menurut Allen et.al (2000), Hoese \& Allen (2015) dan Kottelat et.al (1993). Sedangkan khusus ikan asing/alien diidentifikasi berdasarkan Peraturan Menteri Kelautan dan Perikanan Nomor 41 tahun 2014 tentang tentang larangan pemasukan jenis ikan berbahaya, ikan sapu sapu merupakan kategori ikan terlarang (Kementerian Kelautan dan Perikanan, 2014).

Indek Keanekaragaman (H'), Indeks Keseragaman (E), Indeks Dominansi (D) dan Komposisi spesies (Ks)

Indeks keanekaragaman adalah nilai yang dapat menunjukkan keseimbangan keanekaragaman dalam suatu pembagian jumlah individu tiap spesies. Sedikit atau banyaknya keanekaragaman spesies ikan dapat dilihat dengan menggunakan indeks keanekaragaman. Indeks keanekaragaman mempunyai nilai terbesar jika semua individu berasal dari spesies yang berbedabeda. Sedangkan nilai terkecil didapat jika semua individu berasal dari satu satu spesies saja (Odum, 1983). Indeks keanekaragaman dihitung menggunakan rumus Shannon - Wienner sebagai berikut:

$$
\left(H^{\prime}\right)=-\sum_{i=1}^{s} \text { piln pi }
$$

Dimana:

$\mathrm{H}^{\prime}=$ Indeks keanekaragaman Shannon Wiener

$\mathrm{S}=$ Jumlah spesies ikan

$p i=$ Perbandingan jumlah ikan ke i (ni/N)

Nilai Indeks keseragaman (E), semakin besar menunjukkan kelimpahan yang hampir seragam dan merata antar spesies (Odum, 1983). Formula dari indeks keseragaman Pielou (E) menurut Pielou (1966) dalam Odum (1983) yaitu:

$$
\mathrm{E}=\frac{\mathrm{H}^{\prime}}{\mathrm{H}^{\prime} \max }
$$

$$
\mathrm{H}^{\prime} \max =\ln \mathrm{S}
$$

Dimana:

E = Indeks keseragaman Shannon Wiener

$\mathrm{H}^{\prime} \quad=$ Keseimbangan spesies

H'max = Indeks keanekaragaman maksimum

$\mathrm{S} \quad=$ jumlah seluruh spesies

Kisaran indeks keseragaman antara 0 sampai 1 , semakin kecil nilai keseragaman (mendekati nol) menunjukan bahwa penyebaran jumlah individu tiap jenis tidak sama. Sebaliknya jika nilai keseragaman semakin besar (mendekati 1) maka populasi akan menunjukkan keseragaman (jumlah individu tiap genus dapat dikatakan sama atau tidak jauh berbeda) (Odum, 1993).

Indeks Dominansi dihitung dengan menggunakan rumus indeks dominanasi dari Simpson (Odum, 1993):

$$
\mathrm{D}=\sum(\mathrm{ni} / \mathrm{N})^{2}
$$

Dimana:

D = Indeks Dominansi Simpson

$\mathrm{ni}=$ Jumlah Individu tiap spesies

$\mathrm{N}=$ Jumlah Individu seluruh spesies

Indeks dominansi berkisar antara 0 sampai 1 , dimana semakin kecil nilai indeks dominansi maka menunjukan bahwa tidak ada spesies yang mendominsi sebaliknya semakin besar dominansi maka menunjukan ada spesies tertentu(Odum, 1993).

Sedangkan komposisi spesies adalah perbandingan antara jumlah individu setiap spesies dengan jumlah individu seluruh spesies yang tertangkap, dengan formula yang dimodifikasi dari Fachrul (2007):

$$
\mathrm{Ks}=\frac{\mathrm{ni}}{\mathrm{N}} \times 100 \%
$$


Dimana :

Ks $=$ Komposisi spesies ikan (\%)

$\mathrm{ni}=$ Jumlah individu setiap spesies ikan

$\mathrm{N}=$ Jumlah individu seluruh spesies ikan

\section{HASIL DAN PEMBAHASAN}

\section{Jenis ikan yang ada di aliran Sungai Cibanten}

Keanekaragaman flora dan fauna dalam suatu ekosistem perairan memiliki peranan yang penting untuk menjaga keberlanjutan ekosistem tersebut. Ikan merupakan bagian penting dalam suatu rantai ekosistem perairan. Adanya dominansi suatu ekor spesies ikan dapat menimbulkan ketidakseimbangan lingkungan ekosistem. Penelitian ini menunjukkan bahwa berdasarkan sampling yang dilakukan telah ditemukan 7 spesies jenis ikan di aliran Sungai Cibanten yang terdiri dari 6 jenis ikan asli dan 1 jenis ikan asing berdasarkan Peraturan Menteri Kelautan Nomor 41 tahun 2014. Sebanyak 135 ekor ikan tertangkap pada penelitian ini yang terdiri dari 7 jenis ikan dari 5 family yaitu Cyprinidae 3 jenis, Loricariidae 1 jenis, Palaemonidae 1 jenis, Zenarchopteridae 1 jenis dan Penaeidae 1 jenis (Tabel 1) dengan jumlah masing masing terdapat pada Tabel 2.

Dari sampel yang diperoleh, famili Cyprinidae adalah golongan yang paling banyak ditemukan. Ikan Wader $(R$. argyrotaenia) merupakan spesies dari famili cyprinidae yang paling banyak ditemukan dalam studi ini. Ikan ini sangat umum dengan berbagai spesies menyebar di perairan Indonesia. Beberapa penelitian telah dilakukan untuk mengetahui tentang dinamika jenis ikan wader pari ( $R$. lateristriata) (Sentosa et.al

Tabel 1 Jenis - jenis ikan yang diperoleh di aliran Sungai Cibanten

Table 1 Collected Fish from Cibanten River System

\begin{tabular}{|c|c|c|c|c|}
\hline No. & Nama Lokal & Nama umum & Family & Nama Ilmiah \\
\hline 1. & Ikan Wader & Ikan Wader & Cyprinidae & Puntius binotatus \\
\hline 2. & Ikan Sapu-sapu & Ikan Sapu-sapu & Loricariidae & Pterygoplichthys pardalis \\
\hline 3. & Udang Galah & Udang Galah & Palaemonidae & Macrobrachium rosenbergii \\
\hline 4. & Wader Pari & Wader Pari & Cyprinidae & Rasbora argyrotaenia \\
\hline 5 & Beunteur bintik & Beunteur bintik & Cyprinidae & Puntius sealei \\
\hline 6. & $\begin{array}{l}\text { Ikan Julung- } \\
\text { julung }\end{array}$ & Ikan Julung-julung & Zenarchopteridae & Dermogenys pusilla \\
\hline 7. & Udang Putih & Udang Putih & Penaeidae & Fenneropenaeus indicus \\
\hline
\end{tabular}

Tabel 2 Jumlah ikan yang ditemukan di aliran Sungai Cibanten

Table 2 Number of collected fish in Cibanten River system

\begin{tabular}{|c|c|c|c|c|c|c|c|}
\hline \multirow{2}{*}{ No. } & \multicolumn{2}{|c|}{ Jenis Ikan } & \multicolumn{4}{|c|}{ Jumlah (ekor) } & \multirow{2}{*}{$\mathrm{N}$} \\
\hline & Nama Lokal & Nama Ilmiah & St. I & St. II & St. III & St. IV & \\
\hline 1. & Ikan Wader & P. binotatus & - & - & 3 & - & 3 \\
\hline 2. & Ikan Sapu-sapu & P. pardalis & - & - & 3 & - & 3 \\
\hline 3. & Udang Galah & M. rosenbergii & 39 & 11 & 5 & - & 55 \\
\hline 4. & Wader Pari & R. argyrotaenia & 31 & 22 & - & - & 53 \\
\hline 5. & Beunteur bintik & P. sealei & - & 7 & - & - & 7 \\
\hline 6. & Ikan Julung-julung & D. pusilla & - & - & - & 6 & 6 \\
\hline 7. & Udang Putih & F. indicus & - & - & - & 8 & 8 \\
\hline & Jumlah Total & & 70 & 40 & 11 & 14 & 135 \\
\hline
\end{tabular}


2008). Penelitian siklus kematangan gonad terhadap ikan ini, menunjukkan bahwa ikan ini dapat bereproduksi dalam kurun waktu sepanjang tahun (Diana, 2007). Lebih lanjut, Ginanjar et al (2014) menemukan bahwa jumlah komposisi untuk pemijahan ikan rasbora adalah 2 jantan dan 1 betina dengan derajat pembuahan 85.7-98.61\%. Menurut Budiharjo (2002) ikan dari genus ini juga berpotensi untuk dikembangkan sebagai komoditas budidaya.

Ikan julung-julung (Dermogenys sp) ditemukan di Stasiun IV merupakan ikan yang umum di perairan Asia Tenggara. Di Indonesia, ikan ini tersebar di beberapa daerah seperti Sumatera, Kalimantan, Jawa, Sulawesi dan Bangka (Samuel, 2010). Beberapa studi menunjukkan eksistensi ikan ini di perairan umum seperti waduk (Roesma, 2013) dan sungai-sungai pegunungan (Dalfit, 2012). Kajian genetik ikan ini sudah dilakukan di beberapa lokasi di Jawa Timur (Fitria et al., 2016).

Selain itu, spesies udang galah (Macrobrachium rosenbergii) telah ditemukan dengan jumlah banyak di Stasiun I, II dan III. Meskipun berukuran kecil ( $>5$ $\mathrm{cm})$ dapat dipastikan bahwa jenis udang yang tertangkap adalah udang galah berdasarkan ciri morfologinya. Udang galah merupakan salah satu komoditas penting budidaya perikanan di Indonesia. Ukurannya yang besar dengan gizi yang tinggi, serta pemeliharaan yang mudah merupakan beberapa keunggunlan salah satu family Palaemonidae ini. Beberapa upaya persilangan yang dilakukan untuk meningkatkan kualitas udang galah telah menghasilkan variasi morfologi yang berbeda (Suwartiningsih et al,, 2017). Beberapa penelitian telah menunjukkan bahwa udang galah telah ditemukan di beberapa daerah aliran sungai (Syafrudin, 2016; Fauzi, 2013).

Pada penelitian ini juga telah ditemukan adanya satu spesies ikan air payau yaitu $F$. indicus di bendungan karet (Stasiun IV pengambilan sample). Secara umum, jenis udang ini merupakan udang yang memiliki habitat di lingkungan perairan laut dan estuary. Lokasi Bendungan Karet yang berada di dekat wilayah pesisir merupakan faktor yang bisa menyebabkan keberadaan udang putih ini. Selain itu juga ditemukan ikan wader (Puntius binotatus) di Stasiun III dengan jumlah yang tidak terlalu banyak. Ikan wader ( $P$. binotatus) merupakan ikan asli sumatra dan telah tersebar di seluruh wilayah nusantara. Meskipun sudah bisa dibudidayakan, permasalahan yang banyak ditemukan pada kegiatan pembenihan ikan wader $(P$. binotatus) pada kolam semi intensif yaitu lingkungan yang tidak stabil sehingga mudah terserang hama, kualitas air yang tidak terkontrol dan terjadwal (Aprillia, 2017).

\section{Kategori Jenis ikan}

Dalam penelitian ini, jenis ikan yang diperoleh dapat dikategorikan menjadi 2 jenis yaitu ikan asli dan ikan asing. Jenis ikan asli yang diperoleh yaitu sebanyak 6 jenis yang terdiri dari ikan wader $(P$. binotatus), udang galah (M. rosenberghii), wader pari $(R$. argyrotaenia), beunteur bitnik ( $P$. seale $I)$, julung julung ( $D$. pusilla) dan udang putih ( $F$. indicus). Sedangkan untuk ikan asing yang ditemukan yaitu ikan sapu-sapu ( $P$. pardalis). Berdasarkan Peraturan Menteri Nomor 41 tahun 2014 tentang larangan pemasukan jenis ikan berbahaya, ikan sapu-sapu merupakan kategori ikan terlarang. Dalam peraturan tersebut, terdapat empat spesies ikan sapu sapu yang tergolong invasif yaitu Pterygoplichthys anisitsi, Pterygoplichthys disjunctivus, Pterygoplichthys multiradiatus dan Pterygoplichthys pardalis. Ikan sapu-sapu P. pardalis yang ditemukan pada penelitian ini berada di Stasiun III daerah Kaujon - Kota Serang. Walaupun jumlah ikan sapu-sapu yang tertangkap pada studi ini sangat kecil, tidak menutup kemungkinan bahwa ikan ini bisa

Tabel 3 Komposisi Spesies Ikan

Table 3 Fish Species Composition

\begin{tabular}{|c|c|c|c|c|c|c|c|}
\hline \multirow{2}{*}{ No. } & \multicolumn{3}{|c|}{ Jenis Ikan } & \multicolumn{4}{|c|}{ Komposisi Spesies (\%) } \\
\hline & Family & Nama Lokal & Species & St.I & St.II & St.III & St.IV \\
\hline 1. & Cyprinidae & Ikan Wader & P. binotatus & 44.3 & 55.0 & - & - \\
\hline & & Wader Pari & R. argyrotaenia & 55.7 & 27.5 & 45.4 & - \\
\hline & & Beunteur bintik & P. sealei & - & 17.5 & - & - \\
\hline 2. & Loricariidae & Ikan Sapu-sapu & P. pardalis & - & - & 27.3 & - \\
\hline 3. & Palaemonidae & Udang Galah & M. rosenbergii & - & - & 27.3 & - \\
\hline 4. & Zenarchopteridae & Ikan Julung-julung & D. pusilla & - & - & - & 42.9 \\
\hline 5. & Penaeidae & Udang Putih & F. indicus & - & - & - & 57.1 \\
\hline
\end{tabular}


menjadi berkembangbiak dengan pesat di aliran sungai Cibanten. Hal ini dikarenakan kebiasaan makan ikan sapu-sapu yang bersifat invasif. Ikan sapu-sapu tidak hanya memakan ikan kecil tetapi juga telur telur ikan (Chaichana et al., 2012). Ikan sapu-sapu ini merupakan ikan asing di beberapa negara di asia (Chaichana et al., 2011; Levin et al., 2008; Liang et al, 2005; Peh, 2010; Page \& Robins, 2006). Lebih jauh, ikan sapusapu bisa menimbulkan dampak ekologis seperti perubahan komunitas bentik (Nico et al., 2001), kompestisi dengan ikan lokal (Chaichana \& Jongphadungkiet, 2012), dan ancaman terhadap ikan hampir punah (Cook-Hildreth, 2009).

Jenis ikan asing invasif yang ditemukan, ikan sapusapu dari family Loricariidae hanya ditemukan di Stasiun Pengamatan III dengan tingkat kepadatan relatif yang tidak terlalu tinggi (27.27\%). Sedangkan untuk udang galah ( $M$. rosenberghii) ditemukan di seluruh Stasiun Pengamatan kecuali di hilir daerah aliran sungai (Stasiun Pengamatan IV). Kepadatan relatif untuk masing-masing jenis ikan pada setiap stasiun pengamatan disajikan di dalam Tabel 3.

\section{Indeks Keanekaragaman (H'),} Keseragaman (E) dan Dominansi (C)

Hasil perhitungan menunjukkan bahwa Indeks keanekaragaman di Stasiun pengamatan I, II, III \& IV adalah sebesar $0.687,0.989,1.067$ dan 0.683 . Berdasarkan analisa Shannon-Wiener tersebut dapat diketahui bahwa pada seluruh stasiun pengamatan daerah aliran Sungai Cibanten memiliki indeks keanekaragaman jenis yang rendah (d" 2.0). Selain itu, indeks keseragaman (E) berdasarkan analisa ShannonWiener pada Stasiun pengamatan I, II, III dan IV memiliki tingkat keseragaman yang rendah dengan nilai E sebesar $0.162,0.268,0.445$ dan 0.258 . Indeks dominansi pada pada stasiun pengamatan III memiliki nilai tertinggi dengan $C=0.537$. Sedangkan nilai Indeks dominansi pada stasiun I, II dan IV secara berurutan adalah sebesar $0.487,0.338$ dan 0.267 .

Indeks keanekaragaman (H') ikan di daerah aliran Sungai Cibanten adalah 0.856 dan termasuk dalam kriteria keanekaragaman rendah. Tingkat keanekaragaman yang sedang ini perlu untuk ditingkatkan untuk menjaga keberadaan jenis-jenis ikan pada ekosistem ini, terutama ikan lokal. Akan tetapi, dengan ditemukanya ikan sapu-sapu yang terkenal memiliki sifat invasif pada ekosistem ini perlu adanya tindakan nyata yang dapat mengurangi potensi penurunan keanekaragaman. Hasil penelitian Chaichana \& Jongphadungkiet (2012) menunjukkan tingkat agresivitas ikan sapu-sapu terhadap ikan lokal. Ikan sapu-sapu bahkan mampu memangsa ikan lokal dengan ukuran lebih besar dari tubuhnya dengan mudah. Selain itu, dalam penelitian tersebut juga diketahui bahwa ikan sapu-sapu merupakan ancaman yang nyata karena mereka juga memangsa telur-telur ikan lokal. Ikan ini telah tersebar di beberapa negara di Asia seperti di Taiwan (Liang et al., 2005), Vietnam (Levin et al., 2008), Thailand (Chaichana et al, 2011), India (Singh \& Lakra, 2011) dan di wilayah Asia Tenggara (Page et al., 2006). Indek keanekaragaman dapat ditingkatkan dengan perbaikan eksosistem di daerah aliran sungai Cibanten melalui pengembalian fungsi sungai. Selain itu, peningkatan kesadaran masyarakat untuk tidak membuang limbah rumah tangga mungkin bisa membantu untuk meningkatkan indeks keanekaragaman komunitas ikan. Rifai et.al (1993) menerangkan bahwa keanekaragaman suatu spesies ikan sangat berkaitan dengan faktor biotik dan abiotik lingkungan habitatnya.

Nilai rata-rata indeks keseragaman (E) di daerah aliran sungai Cibanten adalah 0.407. Indeks ini menujukkan bahwa keseragaman ikan di daerah aliran sungai cibanten tergolong sedang dengan kondisi komunitas yang tertekan (Odum, 1993). Kondisi suatu perairan dengan komunitas yang tertekan dapat disebabkan oleh beberapa faktor antara lain adanya limbah yang masuk kedalam wilayah perairan dan adanya introduksi ikan yang bersifat invasive. Kehadiran ikan eksotis atau spesies non-native mungkin menjadi penyebab kondisi tersebut. Sebagai contoh, adanya pemasukan spesies ikan-ikan tertentu baik disengaja maupun tidak disengaja disinyalir mengancam keberadaan spesies ikan asli di Danau Toba Balige (Barus, 2007). Keadaan yang sama juga telah ditemukan sebelumnya telah terjadi di Danau Sentani (Tupen et al., 2016). Penggunaan daerah aliran Sungai Cibanten sebagai sumber air bersih untuk keperluan sehari-hari penduduk di sekitar aliran sungai memungkinkan adanya buangan sampah maupun limbah domestik ke badan sungai yang dapat menyebabkan terganggunya habitat alami ikan. Bukan tidak mungkin tekanan lingkungan di daerah aliran sungai Cibanten merupakan salah satu faktor yang mengakibatkan sedangnya indeks keseragaman di lokasi ini.

Diantara empat lokasi sampling, stasiun sampling III memiliki indeks dominansi yang lebih tinggi dibandingkan dengan stasiun pengamatan yang lain dengan $\mathrm{C}=0.537$. Hal ini menandakan bahwa indeks dominasi di stasiun ini tergolong sedang dengan komunitas yang labil. Pada stasiun sampling III tim menemukan 3 spesies dengan jumlah yang tidak merata dan didominasi oleh ikan wader pari $(R$. argyrotaenia). Sedangkan nilai Indeks dominansi pada stasiun I, II dan IV secara berurutan adalah sebesar $0.487,0.338$ dan 0.267 yang menandakan rendahnya 
indek dominasi suatu jenis spesies ikan yang menandakan struktur komunitas spesies yang lebih baik daripada stasiun sampling III. Akan tetapi, nilai tersebut masih cukup tinggi dan berpotensi menyebabkan komunitas perairan yang tidak sehat dikarenakan adanya satu jenis ikan yang mendominasi ekosistem. Dalam jangka panjang, struktur komunitas seperti ini akan menyebabkan ketidakseimbangan ekosistem tersebut apabila tidak dikendalikan.

Terbatasnya jenis alat tangkap yang digunakan dan periode pengambilan sampel mungkin menjadi penyebab sedikitnya jumlah tangkapan ikan pada penelitian ini. Diketahui bahwa pada penelitian ini hanya digunakan jala tebar, jaring dan serokan sebagai alat tangkap. Selain jenis alat tangkap yang digunakan, Mulk et al. (2016) menyatakan bahwa keanekaragaman jenis, jumlah dan ukuran spesies di suatu perairan dapat dipengaruhi oleh variasi musim dan temperatur perairan.

\section{KESIMPULAN}

Penelitian ini menunjukkan bahwa Daerah Aliran Sungai Cibanten memiliki keanekaragaman jenis ikan yang rendah. Pemanfaatan air sungai yang masif oleh masyarakat disekitar aliran sungai memberikan kontribusi terhadap rendahnya keanekaragaman tersebut. Data yang diperoleh pada penelitian ini diharapkan dapat dijadikan sebagai data dasar kondisi ekosistem Daerah Aliran Sungai Cibanten. Selain itu, data penelitian ini dapat juga digunakan sebagai potret kondisi perairan biodiversitas Sungai Cibanten secara umum. Meskipun ditemukan ikan yang tergolong invasif yaitu Pterygoplichthys pardalis, hasil sampling tidak menunjukkan adanya dominasi oleh spesies tersebut. Akan tetapi, hal tersebut harus menjadi perhatian khusus bagi para stakeholder terkait perikanan dan lingkungan. Perlu adanya pemantauan dan pengambilan data kondisi ikan dan ekosistem secara konsisten sebagai acuan untuk melakukan tindakan sebagai upaya melindungi keanekaragaman dan keseragaman ikan lokal.

\section{DAFTAR PUSTAKA}

Allen, G., Kent, H. G., \& Samuel, R. J. (2000). Freshwater Fishes of the Timika Region New Guinea.

Aprillia, A. W. (2017). TEKNIK PEMBENIHAN IKAN WADER BINTIK DUA (Puntius binotatus). Surabaya: Fakultas Perikanan dan Kelautan, Universitas Airlangga.
Budiharjo. (2002). Seleksi dan Potensi Budidaya Jenisjenis Ikan Wader dari Genus Rasbora. Biodiversitas, 3(2), 225-230.

Chaichana, R., Pouangcharean, S, \& Yoonphand, R. (2011). Habitat, abundance and diet of invasive suckermouth armored catfish (Loricariidae: Pterygoplichthys) in the Nong Yai canal, East Thailand. Tropical Zoology, 49-62.

Chaichana, R., \& Jongphadungkiet, S. (2012). Assessmnet of the invasive catfish Pterygoplichthys pardalis (Castelnau, 1855) in Thailand : ecological impacts and biological control alternatives. Tropical Zoology, 25(4), 173-182.

Cook-Hildreth, S. (2009). Exotic armored catfishes in Texas: reproductive biology, and effects offoraging on egg survival of native fishes (Etheostoma fonticola, endangered and Dionda diaboli, threatened). San Marcos: Texas State University-San Marcos.

Croocks, J. (2002). Characterizing ecosystem level consequences of bioloigcal invasions: the role of ecosystem engineers. Oikos, 972), 153-166.

Dalfit. (2012). Keanekaragaman Jenis Ikan Air tawar di sungai-sungai yan gberasal dari Gunung Salak. Bogor: Institut Pertanian Bogor.

Diana, E. (2007, February 8). Tingkat Kematangan Gonad Ikan Wader (Rasbora argyrotaenia) di sekitar mata air Ponggok Klaten, Jawa Tengah. Surakarta, Jawa Tengah, Indonesia.

Eby, L., Crowder, J., \& Stanford, L. (2006). Effects of stocking-up freshwater food webs. Trends Ecology, 21, 576-584.

Fauzi, A. (2013). Studi Morfologu Udang Galah (Macrobrachium rosenbergii) di aliran sungai Musi, Sumatera Selatan. Bogor: Institut Pertanian Bogor.

Fitria, Ibrohim, \& Listyorini, D. (2016). Kajian Genetik Ikan Julung-julung (Dermogenys sp) berdasarkan DNA Barcode Cytochrome-C Oxidase Subunit 1 di Perairan Kabupaten Pasuruan dan Malang. Jurnal IImu Hayati, 14.

Ginanjar, R., Zamroni, M., \& Nurhidayat. (2014). Optimalisasi Rasio Kelamin yan gberbeda pada pemijahan ikan hias rasbora (Rasbora argyrotaenia). Forum Inovasi Teknologi Akuakultur (p. 947). Depok: Badan Penelitian dan Pengembangan Kelautan dan Perikanan.

Gumelar, R. A. (2016). Kenaekaragaman Organisme Situ Cibanten. Serang: Universitas Sultan Ageng Tirtayasa.

Haryono, Wahyudewantoro, G., Wawing, Tani, D. D., Anggraeni, Y., Arta, A. P., . . Supardan, A. (2016). Jenis Ikan Invasif, Ancaman dan Pengendaliannya. (H. Yuwono, Ed.) Jakarta: Bidang Keamanan Hayati Ikan. 
Herder, F., Schliewen, U., Geiger, M., Hadiaty, R., Gray, S., McKinnon, J., . . . Pfanfer, J. (2012). Allien Invasion in Wallace's Dreampond : Records of the hybridogenesis "flowerhorn" cichlid in Lake Matano, with an annotated checklist of fish species introduced to the Mailili Lakes system in Sulawesi. Aquatic Invasion, 74), 521-535.

Hoese, D., \& Allen, G. (2015). Description of three new species of Glossogobius (Teleostei: Gobiidae) From New Guniea. 201-2016.

Kementerian Kelautan dan Perikanan. (2014). Peraturan Menteri Kelautan dan Perikanan Nomor 41 tahun 2014. Jakarta, Indonesia.

Lever, C. (1996). Naturalized fishes of the world. London: Academic Press.

Levin , B., Phuong , P., \& Pavlov , D. (2008). Discovery of the Amazon sailfin catfish Pterygoplichthys pardalis (Castelnau, 1855) (Teleostei: Loricariidae) in Vietnam. Journal of Applied Ichthyology, 715717.

Liang, S., Wu, H., \& Shieh, B. (2005). Size structure, reproductive phenology, and sex ratio of an exotic armored catfish (Liposarcus multiradiatus) in the Kaoping River of southern Taiwan. Zoological Studies, 2(44), 252-259.

Mulk, S., Korai, A., Azizullah, \& Nasir, M. (2016). Decreased fish diversity found near marble industry effluents in River Barandu, Pakistan. Ecotoxicology, 25, 132-140.

Nico, L., \& Martin , R. (2001). The South American armored catfish, Pterygoplichthys anisitsi (Pisces:Loricariidae), in Texas, with comments on foreign fish introductions in the American Southwest. The Southwestern Naturalist, 46(1), 98-104.

Odum, E. P. (1993). Dasar-dasar Ekologi. Terjemahan : Tjahjono Samingan. Yogyakarta: Gadjah Mada University Press.

Page , L., \& Robins , H. (2006). Identification of sailfin catfishes in southeastern Asia. The Raffles Bulletin of Zoology, 2(54), 455-457.
Peh, K. (2010). Invasive species in Southeast Asia: the knowledge so far. Biodiversity and Conservation, 19, 1083-1099.

Roesma, D. I. (2013). Evaluasi Keanekaragaman Spesies Ikan Danau Maninjau. Prosiding Semirata (pp. 197-204). Lampung: FMIPA Universitas Lampung.

Saifullah, Hermawan, D., \& Purnomo, B. H. (2015). Kualitas Air Situ Cibanten Berdasarkan Nilai Indeks Keanekaragaman Shannon-Weaver. Jurnal Perikanan dan Kelautan, 5(1), 1-4.

Samuel. (2010). Ikan Julung-julung genus Dermogenys. Balai Riset Perikanan Umum. Badan Riset Kelautan dan Perikanan, Pusat Riset Perikanan Tangkap.

Sentosa, A. A., Djumanto, \& Setyobudi, E. (2008). Hubungan Panjang-Berat dan Faktor Kondisi Wader Pari (Rasbora lateistriata) di Sungai Ngrancah, Kabupaten Kulonprogo. Seminar NAsional Tahunan V Hasil Penelitian Perikanan dan Kelautan (pp. 16). Yogyakarta: Univeritas Gajah Mada.

Singh, AK, \& Lakra, WS. (2011). Risk and benefit assessment of alien fish species of the aquaculture and aquarium trade into India. Reviews in Aquaculture , 3-18. .

Suwartiningsih, N., Trijoko, \& Handayani, N. N. (2017). Variasi morfologis udang galah (Macrobrachium rosenbergii de Man, 1879) hasil inbreeding dan outbreeding populasi Probolinggo dan Mahakam. Journal of Tropical Biodiversity and Biotechnology, 2, 57-63.

Syafrudin. (2016). IDENTIFIKASI JENIS UDANG (CRUSTACEA) DI DAERAHALIRAN SUNGAI (DAS) KAHAYAN KOTAPALANGKARAYA PROVINSI KALIMANTAN TENGAH. Palangkaraya: IAIN Palangkaraya.

Tupen, G. P., Ohee, H. L., \& Kurnaningtyas, F. N. (2016). Komposisi Jenis Ikan yang Dilindungi dan Invasive di Perairan Danau Sentani. Jurnal Pembangunan dan Inovasi Papua, 6(2), 97-110. 